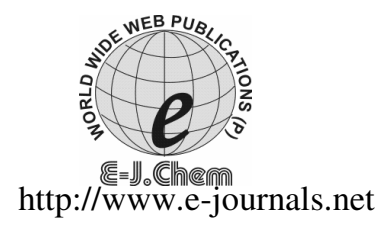

ISSN: 0973-4945; CODEN ECJHAO

E-Journal of Chemistry

2009, 6(S1), S480-S484

\title{
Progressive Corrosion Study of Metals like Mild Steel, Zinc and Aluminium in an Urban Atmosphere
}

\author{
H. K. KADIYA* and R. T.VASHI \\ ${ }^{*}$ C. U. Shah Science College, \\ Ashram Road, Ahmedabad-380014, Gujarat, India. \\ Department of Chemistry, \\ Navyug Science College, Surat - 395009, Gujarat, India. \\ hitesh_1330@yahoo.co.in
}

Received 1 May 2009; Accepted 1 July 2009

\begin{abstract}
Corrosion rate (Progressive) of mild steel (MS), zinc and aluminum have been determined under outdoor conditions of exposure at Valsad (South Gujarat) representing an urban atmosphere. Mild steel (MS), zinc and aluminium plates exposed during November 2005 indicates corrosion rate of 88,33 and 1.4 $\mathrm{mg} / \mathrm{sq} . \mathrm{dm}$ for one month exposure period and 3668, 968 and $26.1 \mathrm{mg} / \mathrm{sq} . \mathrm{dm}$ for mild steel, zinc and aluminium respectively for twelve months exposure period. Mild steel panels exposed vertically suffer less corrosion than those exposed at an angle of $45^{\circ}$. The resistivity towards the atmosphere was in the increasing order: mild steel $<$ zinc $<$ aluminium. Corrosion rate of these three metals was found more in rainy seasons than the rate of winter and summer season.
\end{abstract}

Keywords: Atmospheric corrosion, Urban atmosphere, Mild-steel, Zinc and aluminium.

\section{Introduction}

Urban atmosphere have pollution from domestic fuel consumption, exhaust of motor vehicles, etc. resulting mainly in an increase in sulphur dioxide, sulphuric acid and dirt with a slight increase in $\mathrm{CO}_{2}$ and chloride. Urban atmosphere is similar to rural atmosphere where there is little industrial activity, characterized by pollution composed mainly of $\mathrm{SO}_{\mathrm{x}}$ and $\mathrm{NO}_{\mathrm{x}}$ variety, from motor vehicles and domestic fuel emissions which with the addition of dew or fog, generate a highly corrosive wet acid film on exposed surfaces (deposition rate of $\mathrm{SO}_{2}$ higher than $15 \mathrm{mg} \mathrm{m}^{-2} \mathrm{day}^{-1}$ and that of $\mathrm{NaCl}$ lower than this value). The present study was carried out in an urban atmosphere under outdoor exposure at Valsad situated in South Gujarat.

\section{Experimental}

Test plates of mild steel, zinc and aluminium have the following chemical composition: 
a) Mild steel: C (0.038\%), $\mathrm{Mn}(0.265 \%), \mathrm{S}(0.015 \%), \mathrm{P}(0.011 \%), \mathrm{Si}(0.012 \%), \mathrm{Cr}$ $(0.021 \%), \mathrm{Mn}(0.006 \%), \mathrm{Al}(0.033 \%), \mathrm{Cu}(0.011 \%), \mathrm{Sn}(0.002 \%), \mathrm{Ni}(0.0115 \%)$ and Fe-rest.

b) Zinc: $99.39 \%$ purity, $\mathrm{Pb}(0.03 \% \mathrm{Max}), \mathrm{Cd}(0.02 \% \mathrm{Max}$.) and $\mathrm{Fe}(0.01 \% \mathrm{Max}$.)

c) Aluminum: $99.09 \%$ purity and $\mathrm{Si}(0.53 \%)$.

Test plates are individually mounted on a wooden rack. Special care has been taken that they were electrically insulated from surrounding metallic stand. The frame was placed in parallel outdoor fully exposed condition on the ground level making an angle of $45^{\circ}$ towards the horizontal plane. Another set of mild steel (MS) panels were fully exposed vertically.

Twenty four specimens of each metal (mild steel, zinc and aluminium) were exposed at the same time (i.e. during November 2005). After completion of exposed period, the progressive weight loss of metal was determined. So, we get successive corrosion rates for one month, two months and three months up to twelve months. Similarly, another set was exposed during March 2006.

All tests were carried out in duplicate and mean of the two values were taken. After exposure period, test plates were wrapped in plastic bags and brought to the laboratory for cleaning. Different cleaning solutions were used to clean different metals. Clark's solution ${ }^{1-2}$ were used to remove rust from mild steel made by $2 \% \mathrm{Sb}_{2} \mathrm{O}_{3}$ (antimony oxide), $5 \% \mathrm{Sncl}_{2}$ (stannous chloride) in concentrated $\mathrm{HCl}(100 \mathrm{~mL})$ at room temperature with constant stirring about 15-20 minutes. Zinc plates were derusted by $10 \% \mathrm{CrO}_{3}$ and about $0.2 \mathrm{~g} \mathrm{BaCO}_{3}$ in distilled water $(100 \mathrm{~mL})$ at $25{ }^{\circ} \mathrm{C}$ for about 2 minutes ${ }^{3}$. Corrosion products on aluminium plates were removed by using the solution of concentrated $\mathrm{HNO}_{3}$ containing $\mathrm{CrO}_{3}$ (chromic acid, $50 \mathrm{mg} / \mathrm{lit}$ ) at a room temperature for about 10 minutes $^{4}$.

\section{Results and Discussion}

\section{Meteorological and pollution data}

The average maximum and minimum temperature was found about $310 \mathrm{~K}$ and $291 \mathrm{~K}$ respectively. Relative humidity was higher than the critical humidity value (70\%) for three months in year 2006 and in 2007 (Figure 1). Generally, the rain starts in June and continuous up to October. The data of rain fall (in $\mathrm{mm}$ ) and number of rainy days of the year 2006 and 2007 are mentioned in (Figure 2). Total annual rainfall was found $1540 \mathrm{~mm}$ in 2006 and $2064 \mathrm{~mm}$ in 2007. March, April, May and June are the hot months of the year, whereas December, January and February are considered as cold months.

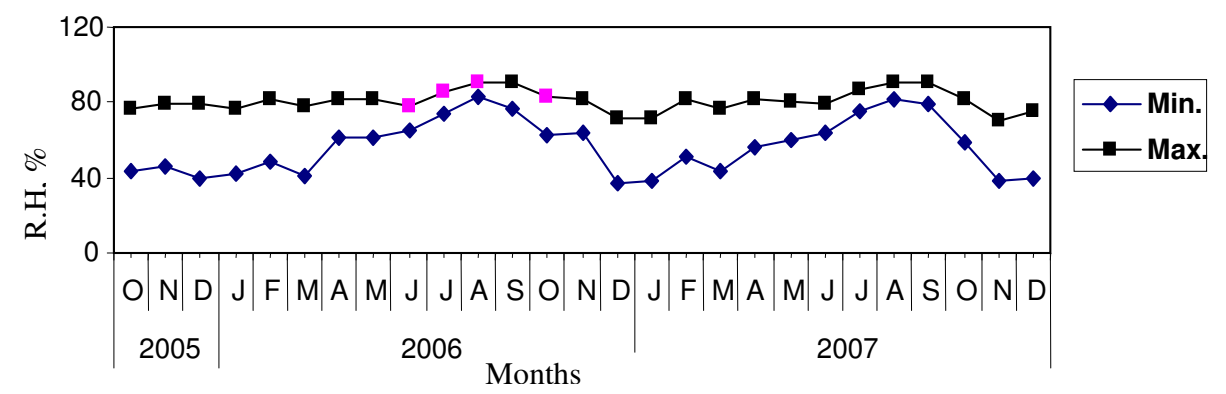

Figure 1. Average relative humidity (R.H.) in percentage at an urban atmosphere.

A sulphation rate was found in a range from 10.2 to $20.2 \mathrm{mg} \mathrm{SO} / \mathrm{Sq} . \mathrm{dm} / \mathrm{month}$. A sulphation rate of $0.03 \mathrm{mg} \mathrm{SO} / 3 / \mathrm{sq} . \mathrm{dm} /$ day $(0.9 \mathrm{mg} \mathrm{SO} / 3 / \mathrm{sq} . \mathrm{dm} / \mathrm{month})$ is usually accepted as representative of clean air ${ }^{5}$. 


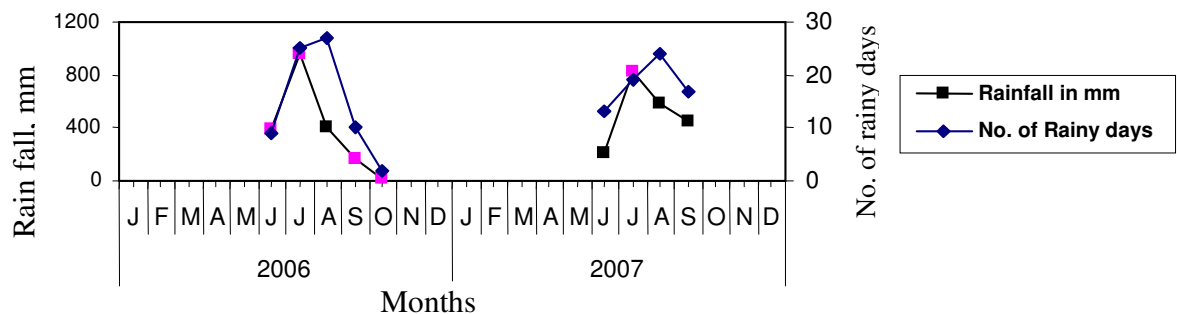

Figure 2. Rain fall (in $\mathrm{mm}$ ) and number of rainy days at an urban atmosphere.

The sulphation rates of different locations are observed as follows: $34.6 \mathrm{mg} / \mathrm{m}^{2} . \mathrm{d} \mathrm{SO}_{2}$ (average 6 months) at $\mathrm{Cuba}^{6}, 0.3$ to $9.0 \mathrm{mg} / \mathrm{SO}_{2} / \mathrm{m}^{2} . \mathrm{d}^{-1}$ of 22 urban atmospheric in the Ibero-American region ${ }^{7}, 0.98 \mathrm{mg} \mathrm{SO}_{3} / \mathrm{sq} . \mathrm{dm} /$ day at Jamshedpur ${ }^{8}$ and $0.85 \mathrm{mg} \mathrm{SO}_{3} / \mathrm{sq} \mathrm{dm} /$ day at Chennai ${ }^{8}$.

Mild steel (MS)

MS plates exposed in winter months (i.e. November 2005) indicates that the corrosion rate increases slowly up to seven months (i.e. up to May 2006) and then it increased rapidly for another five months (i.e. from June-2006 to October 2006). The corrosion rate of mild steel indicates $88 \mathrm{mg} / \mathrm{sq} . \mathrm{dm}$ for one month and $3668 \mathrm{mg} / \mathrm{sq} . \mathrm{dm}$ for twelve months exposure period.

Similarly, plates exposed in summer months (i.e. from March-2006) shows corrosion rate increases rapidly for seven months (i.e. from March 2006 to September 2006), then it remain almost steady for further five months (i.e. from October 2006 to Febuary 2006) (Figure 3).

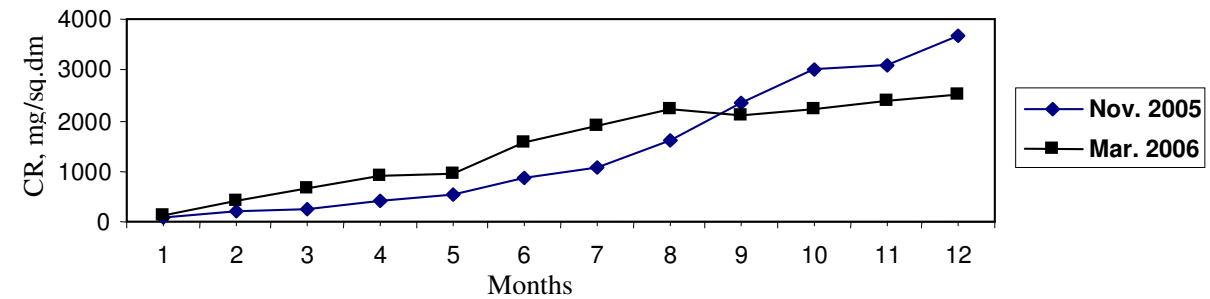

Figure 3. Progressive corrosion rate (CR) of mild steel under outdoor exposure at an urban atmosphere.

\section{Various exposure conditions}

The corrosion rate of MS plates exposed to fully outdoor condition and partly sheltered condition from November 2005 to October 2006 indicates that the corrosivity is more in fully exposed condition (average $421 \mathrm{mg} / \mathrm{sq} . \mathrm{dm} / \mathrm{month}$ ) than the partly sheltered condition (average $267 \mathrm{mg} / \mathrm{sq} . \mathrm{dm} / \mathrm{month}$ ) (Table 1 ).

Zinc

The observation of first set of zinc metals exposed in winter months (i.e. November 2005) indicates that the corrosion rate increases progressively for the first four months i.e. November 2005 to Febuary 2006) and then it steady for further three months(from March 2006 to May 2006) then it increased rapidly for further five months (i.e. from June 2006 to October 2006). The corrosion rate of zinc indicates $33 \mathrm{mg} / \mathrm{sq} . \mathrm{dm}$ for one month and 968 $\mathrm{mg} / \mathrm{sq} . \mathrm{dm}$ for Twelve months exposure period. Another set of plates exposed in summer month (i.e. March 2006) indicates corrosion rate increases slowly for eight months (i.e. from March 2006 to October 2006), then it increased rapidly for further four months (i.e. from November 2006 to Febuary 2007) (Figure 4). 
Table 1. Corrosion rate of mild steel in fully outdoor and partly sheltered condition at an urban atmosphere.

\begin{tabular}{ccc}
\hline & \multicolumn{2}{c}{ Corrosion rate, mg/sq.dm } \\
\cline { 2 - 3 } Month & Fully outdoor & Partly sheltered \\
\hline November 2005 & 78 & 57 \\
December & 75 & 53 \\
January 2006 & 94 & 71 \\
February & 139 & 102 \\
March & 124 & 91 \\
April & 334 & 256 \\
May & 604 & 359 \\
June & 822 & 490 \\
July & 1096 & 664 \\
August & 711 & 499 \\
September & 638 & 375 \\
October & 347 & 190 \\
\hline
\end{tabular}

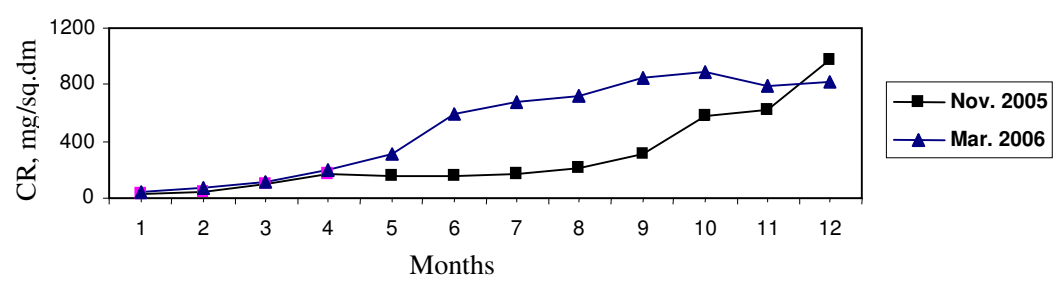

Figure 4. Progressive corrosion rate $(\mathrm{CR})$ of zinc under outdoor exposure at an urban atmosphere.

\section{Aluminium}

Aluminum plates exposed in winter months (i.e. November 2005) indicates that the corrosion rate increases slowly up to eight months (i.e. up to June 2006) then it increased rapidly for another four months ( i.e. from July 2006 to October 2006) (Figure 5). The corrosion rate of aluminium indicates $1.4 \mathrm{mg} / \mathrm{sq} . \mathrm{dm}$ for one month and $26.1 \mathrm{mg} / \mathrm{sq} . \mathrm{dm}$ for Twelve months exposure period.

Another set of aluminium plates were exposed in summer months (i.e. from March 2006). The corrosion rate increase rapidly for seven months (i.e. from March 2006 to September 2006), then it remain almost steady for further five months (i.e. from October 2006 to Febuary 2007) (Figure 5).

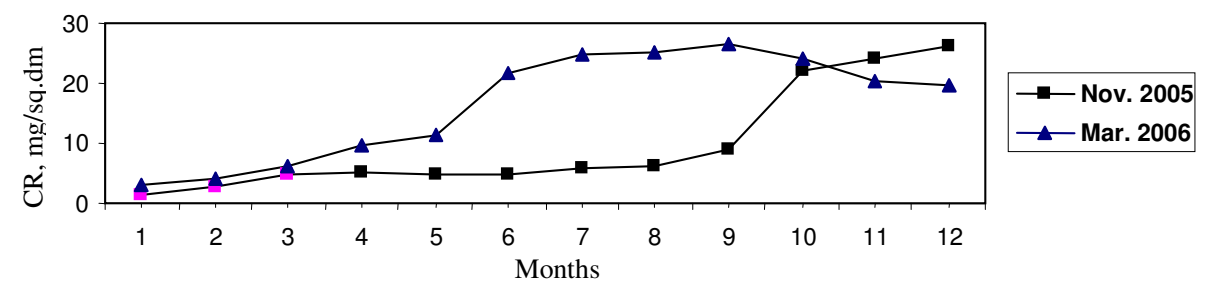

Figure 5. Progressive corrosion rate $(\mathrm{CR})$ of aluminium under outdoor exposure at an urban atmosphere. 


\section{Conclusions}

The resistivity towards the atmosphere was in the increasing order: mild steel $<$ zinc $<$ aluminium. So, we can say that aluminium or aluminium coated sheets would give better performance compared to mild steel or zinc.

\section{Acknowledgements}

The authors are thankful to Department of Chemistry, Navyug Science College, Surat and C. U. Shah Science College, Ahmedabad for providing laboratory facilities.

\section{References}

1. Clarke S G, Trans Electrochem Soc., 1936, 69, 131.

2. Stroud E G, J Appl Chem., 1951, 1, 93.

3. Whitby L, Trans Faraday Soc., 1939, 29, 527, 844.

4. $\quad$ West P W and Gaeke G C, Anal Chem., 1956, 28, 1816-1819.

5. Thomas F W and Davidson C M, J Air Pollut Control Ass., 1961, 11(1), 24-27.

6. Mendoza A R and Corvo F, Corros Sci., 2000, 42, 1123-1147.

7. Almeida E, Morcillo M, Rosales B and Marrocos M, Materials and Corrosion, 2000, 51, 859-864.

8. Singh D D N, Yadav Shyamjeet and Saha Jayant K, Corros Sci., 2008, 50, 93-110. 


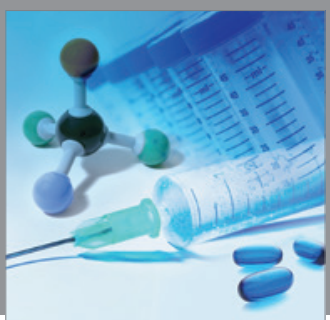

International Journal of

Medicinal Chemistry

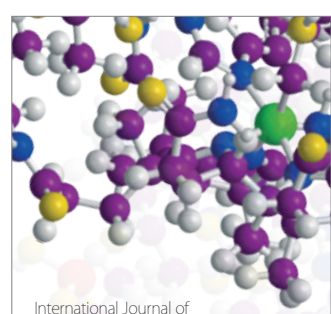

Carbohydrate Chemistry

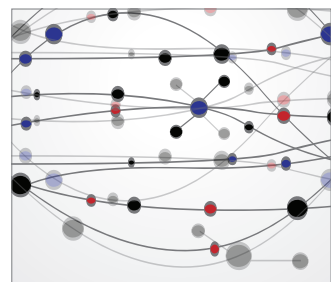

The Scientific World Journal
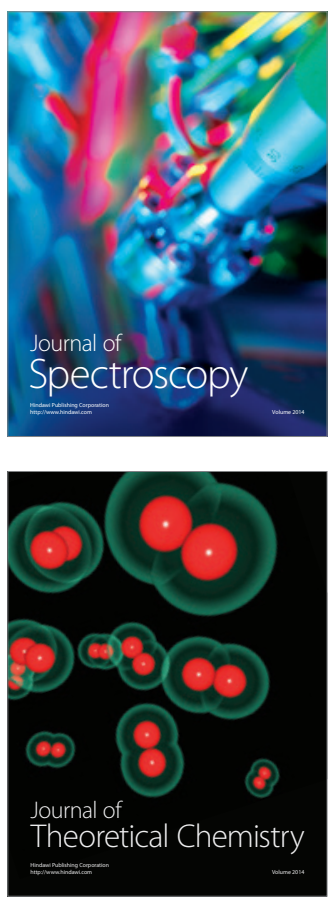
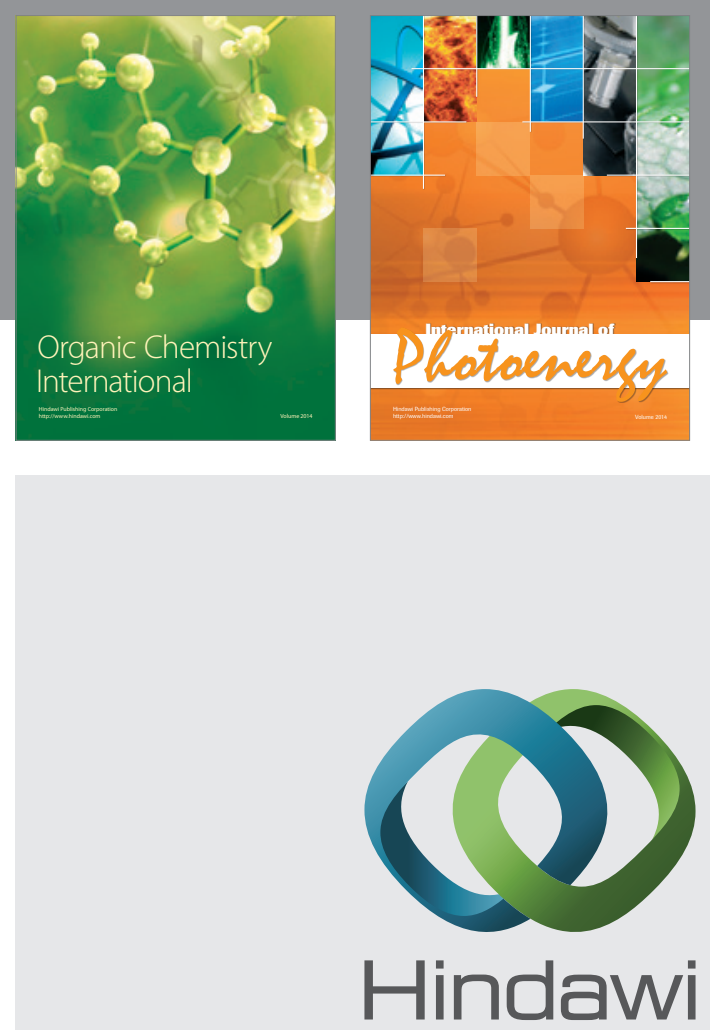

Submit your manuscripts at

http://www.hindawi.com
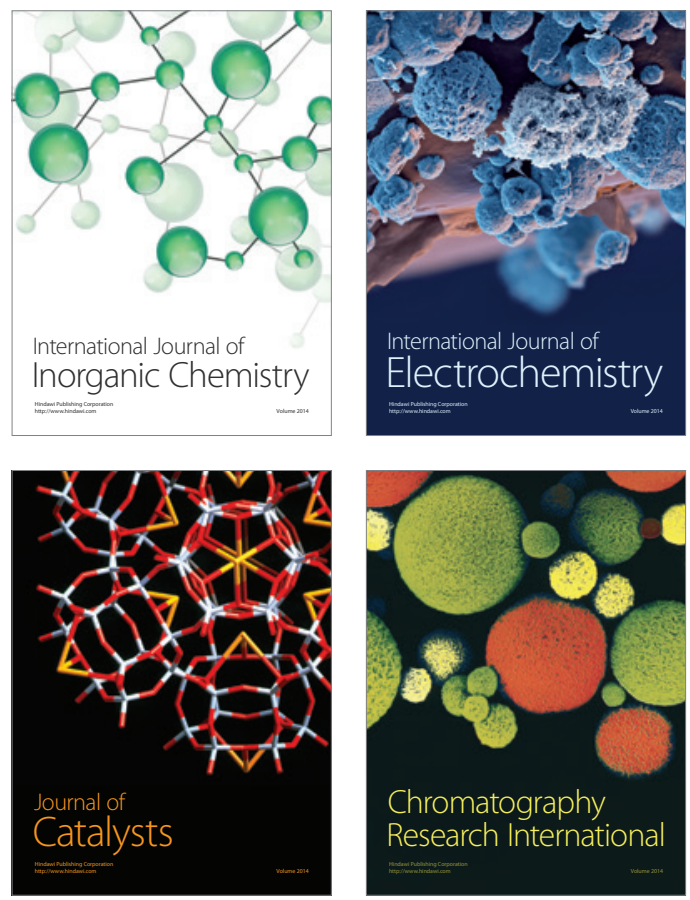
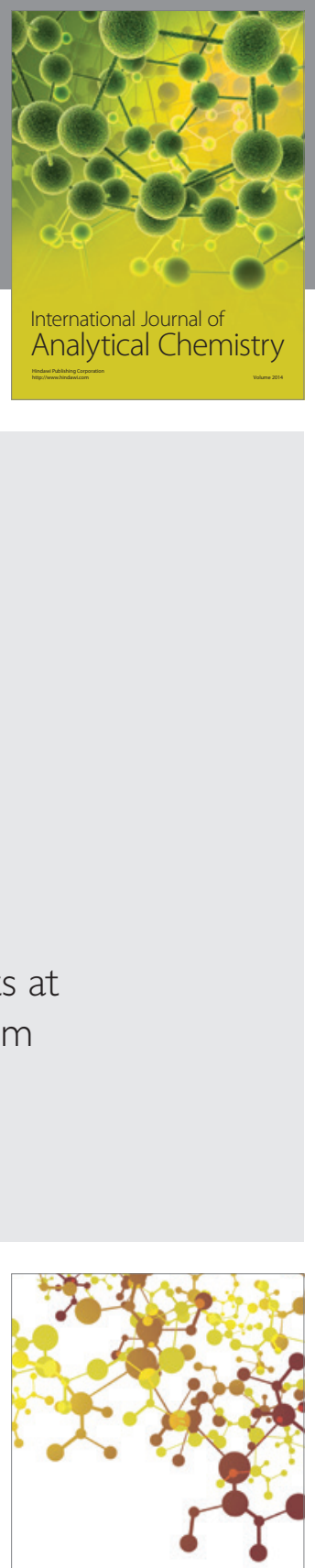

Journal of

Applied Chemistry
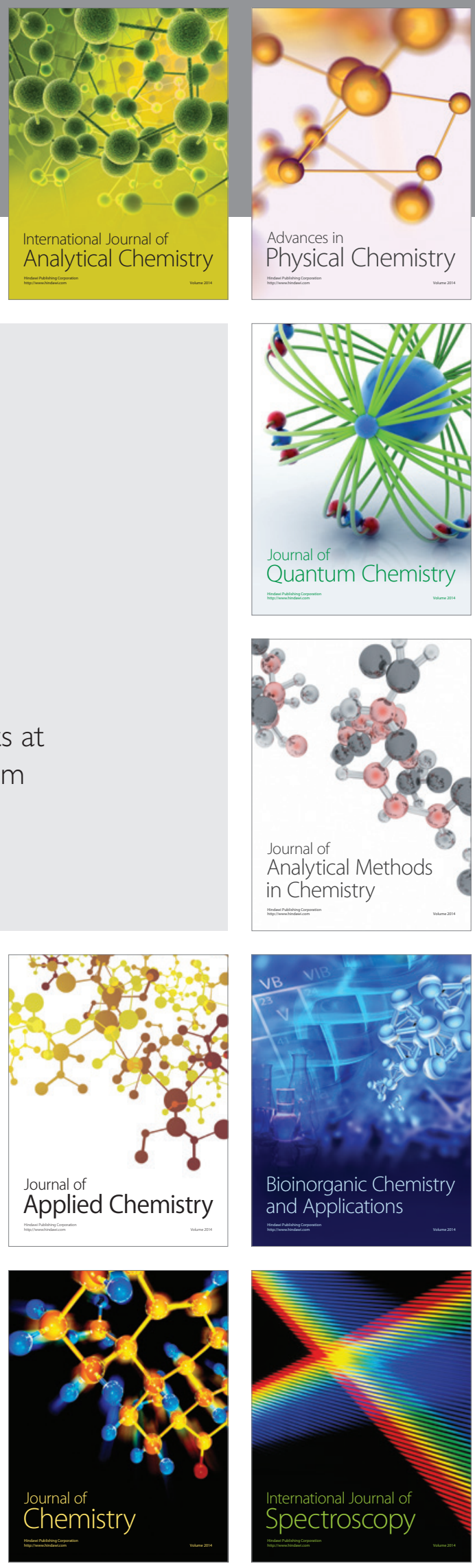